Sección Sur-Sur

\title{
Competitive advantage toward construction project development in the United Arab Emirates
}

Ventaja competitiva hacia el desarrollo de proyectos de construcción en los Emiratos Árabes Unidos

\author{
Mohammed Sultan Mohammed Al-Ali | Universiti Teknikal Malaysia Melaka - MALAYSIA | \\ Corresponding author. E-mail. uaq42@yahoo.com \\ Haslinda Musa | Universiti Teknikal Malaysia Melaka - MALAYSIA | \\ Associate Professor with the Faculty of Technology Management and Technopreneurship, Universiti Teknikal Malaysia, Melaka, Malaysia. E-mail: haslindamusa@utem. \\ edu.my
}

\begin{abstract}
This study aims to examine the impact of competitive advantage on the project development in the United Arab Emirates. This study employed a cross-sectional approach, the data obtained through a questionnaire instrument. The data obtained from 382 respondents from the construction industry. The result confirms a positive and significant impact of competitive advantage on the construction project development.
\end{abstract}

Keywords: Competitive advantages, project development, construction industry, United Arab Emirates

RESUMEN: Este estudio tiene como objetivo examinar el impacto de la ventaja competitiva en el desarrollo del proyecto en los Emiratos Árabes Unidos. Este estudio empleó un enfoque transversal, los datos obtenidos a través de un instrumento de cuestionario. Los datos obtenidos de 382 encuestados de la industria de la construcción. El resultado confirma un impacto positivo y significativo de la ventaja competitiva en el desarrollo del proyecto de construcción.

Palabras clave: ventajas competitivas, desarrollo de proyectos, industria de la construcción, Emiratos Árabes Unidos. 


\section{INTRODUCTION}

Construction industry is a very wide and big industry that allow any state to get very fast development to the whole country in terms of infrastructure and capital income. Construction industry requires the involvement of strategies and innovations to ensure that the construction projects management is being in the right path. Improvement and evolvement of construction Projects Management is a result of strategies and innovations development in the current era. Implementing the right strategies and innovations reduces time and cost of a construction project and deliver it at the exact time (Ball, 2014).

The United Arab Emirates is an Arabian country located at Western Asia at the southeast end of the Arabian Peninsula on the Arabian Gulf, bordering Oman to the east and Saudi Arabia to the south, as well as sharing maritime borders with Qatar to the west and Iran to the north. In 2013, the UAE's population was 9.2 million, of which 1.4 million are Emirati citizens and 7.8 million are expatriates. Recently, the UAE especially Dubai has become one of the most developed Arabian countries in term of construction projects. There are lots of construction projects which emphases the importance of strategies and innovations in the development of construction projects management (Zahlan, 2016)

This research is launched based on the vital role of strategy mediating innovation in the development of construction projects management in general, and the exceptional importance of the United Arab Emirates construction industry, particularly due to the construction boom in the United Arab Emirates.

\section{COMPETITIVE ADVANTAGE}

It is critical to think about that strategic administration in an organization is the key with the goal that it can make a degree of progress in its competitive condition, which leads us to conclude that it is a key apparatus in the board and organization of organizations. Every technique that is introduced must be affirmed by the relating officials, and once it is actualized it is significant that the targets it raises are accomplished. In this sense, we should likewise accentuate that strategic administration isn't restricted to the extent of the organization's targets since once these objectives have been accomplished, strategic administration will have the duty of keeping up the achievement accomplished (Öz, 2019). The dashboards furnish us with a system that is typically helpful for considering the strategic administration that is utilized dependent on the development of value creation; so as to characterize and group what must be done in the foreordained time point of view. The strategic administration must contain those activity designs that serve to explain the movement and the outcomes that are normal at each given minute, moreover, it must indicate in what direction each part that makes up the organization will pay every one of the destinations sought after just as those connections that they should ensure the aftereffects of strategic administration. As far as it matters for them, strategic administration models must have the ability to instigate those procedures of consistent change contingent upon whether the organization is referred to can guarantee a competitive position inside its condition.

The organization accomplishes a competitive advantage when the company buys or builds an element or arrangement of salient points that enable it to overcome its competitors. These characteristics can include access to common assets, such as excellent materials, cheap power, or deep human resource access preparation. As Denrell and Powell (Denrell, 2016) points out, business methodology is an arrangement tool with assets and adds a competitive advantage. As a result, an appropriate business system may be deficient unless it has control over its new assets along with the ability to make a special component. In brief, competitive advantage is one of the fundamental determinants of mainstream performance. In addition, it is intended to ensure a high-level position in the market. The prevailing performance is the ultimate goal required from companies. Thus, competitive advantage aims at achieving such required performance.

Competitive advantage is a complex subject, which covers different issues and focuses on competitive hardware such as quality, speed, development and initiative, and various variables that are inevitable in mechanical and administrative areas. Improving competitiveness is essential to the survival and success of any organization since it enables it to play a crucial role in its industry. Before companies can compile a competitive advantage that can be maintained, it needs to take a competitive fire plan methodology (Liao, 2015). A competitive system is characterized as an attacker or a guard of its activities in taking a cautious position in business or negotiating effectively with competitive authorities, thus producing a higher degree of profitability for firms (Kotler, 2015). For examples, corporate social duty and customer actions such as CRM give a wonderful management, great, cost initiative, and separation.

A theory of competitive advantage without the likelihood of non-routine activity by the best management group is clumsy, and the dynamic system of capacities has never been intended to block non-routine activity. Eisenhardt and Martin (Eisenhardt, 200) study shows an intense attention to the part of supervisors, including their "pas- 
sionate failure to adapt to vulnerability in high-speed markets". However, their contention about the inborn shortcoming of dynamic abilities theory in high-speed situations utilizes just the dialect of procedures and principles.

The competitive advantage is the capacity of an organization to conquer another or others of a similar industry or division through procedures that are not really characterized. Each organization can advance in its own particular manner. Be that as it may, these competitive advantages can't generally be kept up for quite a while in light of the fact that the business sectors are continually changing and organizations must be aware of these progressions so as not to "leave style" with the competitive advantages they create.

Through competitive advantages, it is workable for an organization to procure a good position in connection to rivalry inside the market. For this, there are sure techniques that advance the great situating of the organization which must be splendidly executed. When discussing competitive advantage, reference is made to two basic ideas: cost administration and separation; however, it envelops five powers rivalry from which it is conceivable to quantify the degree. An advantage or trademark that an organization has contrasted with other contending organizations is known as a competitive advantage, which makes it unique and enables more shoppers to be pulled in. An organization has a competitive advantage when it has a one of a kind and practical advantage over its rivals, and this advantage enables it to get better outcomes and, along these lines, to have an unrivaled competitive position in the market. There are numerous sources to create this sort of advantages, for example, the area of our organization, quality, and innovations in the items we make, the administration we offer or lower generation costs among others. Competitiveness decides the achievement or disappointment of organizations. All together for an organization to get by in any competitive market, it must outperform its rivals, and for this, it is totally vital that it make and build up a feasible competitive advantage. The idea was created in 1980 by Michael Porter, thought about the dad of corporate procedure. The rundown of potential competitive advantages is broad. There are the individuals who imagine that in such an evolving market, there are actually no competitive advantages that can be kept up for quite a while. It is said that the main long-haul competitive advantage is that an organization can be alert and nimble enough to consistently discover an advantage regardless of what may occur. The competitive advantage is one of the business the executives pointers and is identified with the plan of action, its systems dependent on the instruments or canvases of procedure age and with the value bend relating to degree issues and hindrances to rivalry (Zhao, 2017).

\section{PROJECT DEVELOPMENT}

Construction industry is a very competitive and high-risk business. This competitiveness is largely due to cost which is usually the main factor in the process of precise identification. A recent study by Australian construction architects showed overwhelmingly that temporary workers and subcontractors see their market achievements dictated by their organization's ability to be the minimum cost of saving $-75 \%$ of the respondents put in the lowest cost accommodation as a key goal behind the delicate sense of achievement. The more competitive the market is, the faster the cost must be accurate is with the consequent lower net revenue. It is widely understood that the traditional single amount or the display of stable value can be a merciless movement. The contracting companies take a stab at a competitive advantage, which gives them a more lucrative offer to award projects (Aznar 2017).

Park affirms that while granting agreements to build a construction chip away in the premise of competitive advantages of owners and contractual workers, a large number of business issues can be attributed specifically to the act of making the basis value only. The competitiveness of companies is exacerbated when the conflicting objectives between contracting and subcontracting companies set the stage for developing a hostile and destructive methodology. A report prepared by the National Conference on Public Works and the Joint Working Group of the National Construction Council showed that in the late 1980s, the Australian construction industry had significant increases in the rate of legally binding cases and debate in contrast to the past 10 years. This pattern has continued to expand the scope of the question and the claims, and the minds of mental loss have progressed gradually with the hostile relations among its project colleagues, specifically between temporary workers and subcontractors. The report also stressed that there is no profit accruing according to circumstances that demand reason and question; and that participation should be enabled at a later date, it stressed the condition of changing the industry.

The construction market is sometimes perceived as a kind of commodity market, that is, there is no clear distinction or differentiation between the companies and the product they can deliver to us, that is: the concrete produced by Company $A$ is equal to the concrete produced by Company B. This sometimes leads us to the error of deciding only for the price of the finished product, without taking into account the way in which this decrease materializes and the process or service offered in its Integrity, which can make a big difference (Zhang, 2019).

When it thinks of decision-making only by price, it is reminded of the phrase of a colleague who said, as obvious as it may seem, "things are worth it". What this phrase implies is that if under construction we buy a product at a lower price than usual and there is no sustainable support to justify the lower value, in the end we will always end 
up paying what was originally worth to the market in general and in many times including a higher price with other associated consequences, such as: non-compliance with deadlines, loss of image and, something that becomes increasingly important, eventual impact and reactions of the community in case it is affected by the breaches.

\section{METHODOLOGY}

For this study, the population is the total staff those work in unlisted construction companies in UAE. According to the National Economic Register (NER, 2018) the total unlisted construction companies operating in the $\mathrm{UAE}$ is 11,676 . And for the samples of this study according to the sample size table of Krejcie and Morgan (Krejcie, 1970), 384 respondents managers in the middle management level from different construction companies is selected.

According to Huang, et al. (Huang, 2015) firm gains competitive advantage when its marginal profit exceed its competitors. In this text, the competitive advantage is measured by 21 items divided into three dimensions, which adopted from the study of Pamulu (Pamulu, 2010), first dimension composites of seven items, these items refer to the manner in which the firm combines its assets/resources and capabilities to reduce its costs to a highly competitive level, while the second dimension consists seven items, these items represent the manner in which the firm combines assets/resources and capabilities to fully exploit all targeted market opportunities, and the third dimension also has structured by seven items, these items represent the manner in which the firm combines its assets/resources and capabilities to defend against all known competitive threats. All these 21 items are scaled based on Likert five points scale from strongly disagree to strongly agree. According to Barclay and Osei-Bryson (Barclay, 2010) project development is linked to the firm ability toward enhancing its performance through 13 objectives. A total of 9 indicators are used to measure the project development, which are adopted from the study of Barclay and Osei-Bryson (Barclay, 2010). Five points Likert scale is used from 1 much worse to 5 much better

\section{FINDINGS}

The current test is used to make sure that the random sampling method was used in the process of distributing the questionnaires. This method aims to ensure that all the population of the study have an equivalent chance to be participating in the research. This test has included 5 main criteria to identify the participants, which are gender, age, educational level, income level, and experience. The following table 1 shows the results of this test, followed by some explanations.

Table 1 Profile of Respondents ( $\mathrm{N}=382)$

\begin{tabular}{|c|c|c|c|c|c|}
\hline $\begin{array}{c}\text { Category } \\
\text { Gender }\end{array}$ & $\begin{array}{c}\text { Frequen- } \\
\text { cy }\end{array}$ & $\%$ & $\begin{array}{c}\text { Category } \\
\text { Education level }\end{array}$ & $\begin{array}{c}\text { Frequen- } \\
\text { cy }\end{array}$ & $\%$ \\
\hline Male & 283 & 74.3 & Diploma & 85 & 22.4 \\
\hline Female & 99 & 25.7 & Bachelor & 246 & 64.5 \\
\hline Age & & & Master & 51 & 13.2 \\
\hline $17-25$ yrs & 60 & 15.8 & Income level USD & & \\
\hline $26-30$ yrs & 123 & 32.2 & $500-750$ & 14 & 3.9 \\
\hline $31-35$ yrs & 65 & 17.1 & $751-1,000$ & 40 & 10.5 \\
\hline $36-40$ yrs & 40 & 10.5 & 1,001 and above & 328 & 85.5 \\
\hline$>40$ years & 94 & 24.3 & Experience (Yr) & & \\
\hline & & & 1 to 3 & 55 & 14.5 \\
\hline & & & 4 to 6 & 153 & 40.1 \\
\hline & & 7 to 9 & 174 & 45.4 \\
\hline
\end{tabular}

The first criteria, which is gender, in these criteria, the participants of the research have shown that the majority of participants were from the male category with $74.3 \%$ and $n=283$ participants. While the female category had only $25.7 \%$ of the total participants and $n=99$ participants.

The second criteria, which is age, in these criteria the participants of the research have shown the majority of participants were from the $26-30$ years old category with $32.2 \%$ and $n=123$ participants. Also, the $17-25$ years old category has recorded a $15.8 \%$ with $n=60$ participants. In the same line, the $31-35$ years old category has recorded a $17.1 \%$ with $n=65$. The lowest participating category was the $36-40$ years old category that got only $10.5 \%$ with $n=40$. Finally, the above 40 years old category has recorded $24.3 \%$ and $n=94$, which is considered to be 
the second highest category in this test. The third criterion, which is educational level, in these criteria the participants of the research have shown that there were only three types of qualifications for all the participant, which are diploma, bachelor, and master. The bachelor category has recorded the highest category with $64.5 \%$ and $n=246$. Also, the diploma category has recorded $22.4 \%$ and $n=85$. Finally, the master category has recorded $13.2 \%$ and $n$ $=51$. The fourth criteria, which is income level, in these criteria the participants of the research have shown that the majority of the participants were in the category of above $\$ 1001$ USD with $85.5 \%$ and $n=328$. In the same regard, the category of $\$ 751-1,000$ has recorded a $10.5 \%$ with $n=40$. Finally, the category of $\$ 500-750$ has recorded a $3.9 \%$ and $n=14$. The fifth and last criterion, which is experience, in these criteria the participants of the research have shown that there were only three periods of experience for all the participant, which are 1-3 years, 4-6 years, and 7-9 years. The 1-3 years has recorded a $14.5 \%$ with $n=55$, While $4-6$ years has recorded a $40.1 \%$ with $n=153$. Finally, the 7-9 years has recorded a $45.4 \%$ with $n=174$.

According to the results found in table 2, the data reveals that there was great internal consistency among the research items, where all the variables recorded scores of higher than 0.7 for both tests, the Cronbach's Alpha and Composite Reliability.

Table 2: Cronbach's Alpha and Composite Reliability

\begin{tabular}{|l|c|c|}
\hline Constructs & $\begin{array}{l}\text { Cronbach's alpha } \\
(>0.7)\end{array}$ & $\begin{array}{l}\text { Composite Reli- } \\
\text { ability }(>0.7)\end{array}$ \\
\hline Competitive advantage & 0.824 & 0.849 \\
\hline Project development & 0.901 & 0.921 \\
\hline
\end{tabular}

The direct effect is the test that is used to find out the direct impact of the independent variables on the dependent variable. The independent variable that competitive advantage, while the dependent variable is project development. The following table 3 shows the values that reveals the positive and significant relationships.

Based on table 3 , it is shown that There is a positive and significant relationship between competitive advantage and project development at $(\beta=0.236, t=1.867, p=0.040)$.

Table 3: Summary of the Direct Effect

\begin{tabular}{|l|l|l|l|l|l|}
\hline Hypothesis & Relationship & $\begin{array}{l}\text { Std } \\
\text { Beta }\end{array}$ & $\begin{array}{l}\text { Std } \\
\text { Error }\end{array}$ & t-value & p-value \\
\hline H1 & CA -> PD & 0.236 & 0.193 & 1.867 & 0.040 \\
\hline
\end{tabular}

Key: CA: Competitive advantage, CP: Capability, RS: Resources, VL: Value, PD: Project development

*significance at confident level $90 \%$ and significance level 10

According to the previous studies, the importance of specified strategy for the industry to accomplish advantage that is competitive ever increasing (Tsai, 2011), because innovation is the engine of competition and determiner of competitive positions of sectors (Jacobsen, 2019). The competitiveness of a company is determined by the activities that it carries out every day from the most specific to the most general. The value chain separates each of the activities of the company in order to understand in greater depth the costs and sources of differentiation of each of them and achieves better quality. Companies differed from each other depending on the industrial sector in which they develop and focus because the more involved they are in meeting the needs of the buyers that are part of their sector, the more preference they will have and is positioned by above its competitors, which will automatically increase its value. When talking about value, Reference is made specifically to the amount that the customer is willing to pay for a certain service or product. There are two types of activities by a company; primary activities and support activities. The value chain of a company is the basis for decision-making in order to achieve a good functioning because each of them provides a base point in sequence with the others, this means that an activity and the good performance of it, it depends on the previous activity, or else there would be a functioning deficit within the activities of the value chain. When the company lowers the price of its products, the buyer has a greater power of choice at the time of the purchase decision taking into account aspects such as their quality and cost. If the value of a company is focused on a certain market and the company retains characteristics similar to the others but with distinctive qualities, it speaks of a competitive landscape by segment. Otherwise, if the company divides its manufacturing activities into multiple points, it are talking about integration and finally when talking about the geographic competitive landscape, reference is made to the geographical location of the plants that offer products and services around the world (Bhattacharya, 2016). 
A competitive advantage is any normal for an organization, nation or individual that separates it from others by putting it in a better relative position than contend. That is a property that makes it more competitive than the others. In any case, it can refer to for instance the advantageous access to characteristic resources, (for example, high-grade minerals or minimal effort vitality sources), profoundly talented work, geographic area or high section obstructions, which can be improved in the event that it have an item that is not really imitable Or it have an incredible brand.

\section{CONCLUSION}

This study investigates the impact of competitive adventage on the construction project development in the UAE. Due to the rapid development in the construction industry in the UAE, construction companies strive to maintain its position within the market. The result of this study reveleaed a significant and positive impact of the competitive adventage toward the construction project development. In this regard, it recommend for companies to revise its strategies that comensurate the firce competion within the market.

\section{BIBLIOGRAPHIC REFERENCES}

Aznar, B., Pellicer, E., Davis, S., \& Ballesteros-Pérez, P. (2017). "Factors affecting contractor's bidding success for international infrastructure projects in Australia," Journal of Civil Engineering and Management, vol. 23, pp. 880-889.

Ball, M. (2014). Rebuilding Construction (Routledge Revivals): Economic Change in the British Construction Industry: Routledge

Barcla, C., \& Osei-Bryson, K. M. (2010). "Project performance development framework: An approach for developing performance criteria \& measures for information systems (IS) projects," International Journal of Production Economics, vol. 124, pp. 272-292.

Bhattacharya, A., Cheffi, W., Dey, P. K., Kato, T., \& Nunes, B. (2016). "Is keiretsu really a source of competitive advantage for Japanese automotive suppliers?" Journal of Manufacturing Technology Management.

Denrell, J. \& Powell, T. C. (2016). "Dynamic capability as a theory of competitive advantage: contributions and scope conditions".

Eisenhardt, K. M., \& Martin, J. A. (2000). "Dynamic capabilities: what are they?" Strategic management journal, pp. $1105-1121$.

Huang, K. F., Dyerson, R., Wu, L. Y., \& Harindranath, G. (2015). "From temporary competitive advantage to sustainable competitive advantage," British Journal of Management, vol. 26, pp. 617-636.

Jacobsen, H. K., Hevia-Koch, P., \& Wolter, C. (2019). "Nearshore and offshore wind development: Costs and competitive advantage exemplified by nearshore wind in Denmark," Energy for Sustainable Development, vol. 50, pp. 91-100.

Kotler, P. (2015). Framework for marketing management: Pearson Education India.

Krejcie, R. V., \& Morgan, D. W. (1970). "Determining sample size for research activities," Educational and psychological measurement, vol. 30, pp. 607-610

Liao, T. S., Rice, J., \& Lu, J. C. (2015). "The vicissitudes of competitive advantage: Empirical evidence from Australian manufacturing SMEs," Journal of Small Business Management, vol. 53, pp. 469-481.

NER. (2018). "Total Number of Licenses Per Business Activity," National Economic Register Abu Dhabi

Öz, Ö. (2019). The Competitive Advantage of Nations: The Case of Turkey: Assessing Porter's Framework for National Advantage: Routledge

Pamulu, M. S. (2010). "Strategic management practices in the construction industry: a study of Indonesian enterprises," Queensland University of Technology.

Tsai, K.H., Hsieh, M. H., \& Hultink, E. J. (2011). "External technology acquisition and product innovativeness: The moderating roles of R\&D investment and configurational context," Journal of Engineering and Technology Management, vol. 28, pp. 184-200

Zahlan, R. S. (2016). The Making of the Modern Gulf States: Kuwait, Bahrain, Qatar, the United Arab Emirates and Oman vol. 10: Routledge

Zhang, N., Deng, X., Zhao, X., \& Chang, T. (2019). "Exploring the sources of contractors' competitive advantage on international HSR construction projects," International Journal of Civil Engineering, vol. 17, pp. 1115-1129.

Zhao, Z. Y., Tang, C., Zhang, X., \& Skitmore, M. (2017). "Agglomeration and competitive position of contractors in the international construction sector," Journal of construction engineering and management, vol. 143, p. 04017004, 2017.

How to cite this article: Mohammed Al-Ali, M. S., \& Musa, H. (2020). Competitive advantage toward construction project development in the United Arab Emirates. Religación. Revista De Ciencias Sociales Y Humanidades, 5(23), 171-176. Retrieved from http://revista.religacion.com/index.php/religacion/article/view/611

Submitted: 28 November 2020 Accepted: 09 March 2020 Published: 31 March 2020

Religación. Revista de Ciencias Sociales y Humanidades is a peer-reviewed open access journal published by CICSH-AL Centro de Investigaciones en Ciencias Sociales y Humanidades desde América Latina |Religación| 